\title{
MENINGKATKAN KREATIVITAS BELAJAR BIOLOGI SISWA MELALUI PENERAPAN METODE QUANTUM TEACHING DI MADRASAH ALIYAH NAHDATUL ULAMA BATANG TORU
}

\author{
Herdiani, Sahlan Tuah, N. Ginting \\ Pendidikan Biologi, FKIP Universitas Muhammadiyah Tapanuli Selatan \\ nurmaini.ginting@um-tapsel.ac.id
}

\begin{abstract}
This research was carried out Madrasah Aliyah Nahdatul Ulama Batang Toru years lessons 2015-2016. This type of research is Research Action class (Classroom Action Research) using two cycles of learning. Each cycle starting from the planning, implementation, observation, and reflection. Data collecting techniques used is the test of creativity and observation. Data collection tools used is sheet tests the creativity and student activity observation sheet. Based on the results of the research action class that do obtain test results of creativity learning of biology students ranging from cycle to cycle I II was 1872 with an average of 72.0 with the percentage of completeness $(61.5 \%)$ and cycle II 2191 with an average completeness percentage with $84.27(84.62 \%)$. Based on the analysis of data obtained the value of the observation activities of students in cycle I of $66.92 \%$ and cycle II of $82.30 \%$ observation rating and performance teacher at $67.25 \%$ of cycle I and cycle II of $92.9 \%$. In cycle II, has experienced an increase of cycle I and already meets the criteria of research indicators of achievement, then this study finalized on cycle II.
\end{abstract}

Keywords: Creativity, Quantum Teaching method, structure and function of plant tissue.

\begin{abstract}
Abstrak
Penelitian ini dilaksanakan Madrasah Aliyah Nahdatul Ulama Batang Toru tahun pelajaran 2015-2016. Jenis penelitian ini adalah Penelitian Tindakan Kelas (Classroom Action Research) dengan menggunakan dua siklus pembelajaran. Tiap siklus dimulai dari perencanaan, pelaksanaan, pengamatan, dan refleksi. Teknik pengumpul data yang digunakan adalah tes kreativitas dan observasi . Alat pengumpulan data yang digunakan adalah lembar tes kreativitas dan lembar observasi aktivitas siswa. Berdasarkan hasil penelitian tindakan kelas yang dilakukan diperoleh hasil tes kreativitas belajar biologi siswa mulai dari siklus I sampai siklus II adalah 1872 dengan rata-rata 72,0 dengan persentase ketuntasan $(61,5 \%)$ dan siklus II 2191 dengan rata-rata 84,27 dengan persentase ketuntasan $(84,62 \%)$. Berdasarkan analisis data diperoleh nilai observasi aktivitas siswa pada siklus I sebesar $66,92 \%$ dan pada siklus II sebesar $82,30 \%$ dan nilai observasi kinerja guru pada siklus I sebesar $67,25 \%$ dan pada siklus II sebesar $92,9 \%$. Pada siklus II sudah mengalami peningkatan dari siklus I dan sudah memenuhi kriteria pencapaian indikator penelitian, maka penelitian ini disudahi pada siklus II.
\end{abstract}

Kata Kunci: Kreativitas, metode Quantum Teaching, struktur dan fungsi jaringan tumbuhan. 
Herdiani, dkk. Meningkatkan Kreativitas Belajar Biologi...

\section{PENDAHULUAN}

Pembelajaran merupakan proses yang diselenggarakan oleh guru untuk membelajarkan siswa dalam memperoleh pengetahuan, keterampilan, dan sikap. Pembelajaran menurut teori behavioristik ditekankan pada penambahan pengetahuan, sedangkan belajar sebagai aktivitas yang menuntut siswa untuk mengungkapkan kembali pengetahuan yang sudah dipelajari dalam bentuk laporan, kuis, atau tes (Dimyati dan Mudjiono, 2006).

Dalam proses pembelajaran diperlukan kreativitas dari siswa sehingga proses belajar mengajar lebih menarik. Menurut Suryosubroto (2009) Kreativitas adalah kemampuan untuk melahirkan sesuatu yang baru, berupa gagasan maupun karya nyata dalam bentuk ciri-ciri aptitude maupun tidak, dalam karya baru maupun kombinasi dengan hal-hal yang sudah relatif dengan apa yang telah ada.

Untuk meninngkatkan kreativitas seorang guru harus mampu memilih model pembelajaan yang dapat mempengaruhi hasrat keingintahuan siswa dan bersipat terbuka, sehinggga keinginan siswa untuk mengemukakan dan meneliti lebih tinggi. dalam kegiatan kelompok siswa dapat bertukar pikiran dengan teman kelompoknya dalam memecahkan masalah yang dihadapinya. Ada banyak tipe pembelajaran kooperatif salah satu diantaranya adalah penerapan metode Quantum Teaching.

Quantum Teaching adalah pengubahan belajar yang meriah dengan segala nuansanya. Dalam quantum teaching juga menyertakan segala kaitan interaksi dan perbedaan yang memaksimalkan momen belajar. Quantum teaching berfokus pada hubungan dinamis dalam lingkungan kelas. Interaksi yang menjadikan landasan dan kerangka untuk belajar (De porter., 2004).

\section{METODE}

Adapun jenis penelitian ini adalah jenis penelitian tindakan kelas PTK Classroom Action Research (CAR). Sesuai dengan Model Menurut Kurt Lewin Sedangkan metode penelitian dalam hal ini adalah metode Quantum Teaching untuk meningkatkan kreativitas belajar biologi siswa khususnya materi struktur dan fungsi jaringan tumbuhan. Penelitian ini dilakukan dalam II siklus yang masing-masing terdiri dari 4 tahapan yaitu planning (perencanaan), acting (pelaksanaan), observation (pengamatan) dan refleksi (reflecting).

Subjek penelitian adalah sesuatu yang menjadi tempat sasaran penelitian, dan ada dalam wilayah penelitian, dalam penelitian ini adalah dilaksanakan dikelas XI Madrasah Aliyah Nahdatul Ulama Batang Toru tahun Pelajaran 2016-2017 yaitu dari siswa kelas XI-1 yang berjumlah 26 siswa.

\section{Alat Pengumpul Data}

\section{(1) Tes}

Tes diberikan setelah materi diajarkan berbentuk essay berjumlah 30 butir soal. Pada siklus I diujikan sebanyak 15 butir soal sedangkan pada siklus II sebanyak 15 butir soal. Untuk menguji tes yang baik diperlukan langkah-langkah dalam menyusun data sebagai berikut:

Validitas Tes : $\mathrm{r}_{\mathrm{xy}}=\frac{N \Sigma X Y-(\Sigma X)(\Sigma Y)}{\sqrt{\left.\left\{N . \Sigma X^{2}-(\Sigma X)^{2}\right\}, N . \Sigma Y^{2}-(\Sigma Y)^{2}\right\}}}$

Keterangan :

$\mathrm{r}_{\mathrm{xy}}=$ koefisien validitas tes

$\sum \mathrm{x}^{2}=$ jumlah kuadrat variabel $\mathrm{x}^{2}$

$\sum \mathrm{x}=$ skor yang diperoleh siswa untuk tiap nomor soal

$\sum \mathrm{y}=$ skor total

$\sum \mathrm{y}^{2}=$ jumlah kuadrat variabel $\mathrm{y}^{2}$

$\sum \mathrm{xy}=$ jumlah hasil kali variabel $\mathrm{x}$ dan $\mathrm{y}$

Reabilitas Tes : $r_{11}=\left(\frac{n}{n-1}\right)\left(1-\frac{\sum \sigma_{i}^{2}}{\sigma_{i}^{2}}\right)$

Dimana :

$\mathrm{r}_{11}=$ Reliabilitas yang dicari

$\sum \sigma_{i}^{2}=$ Jumlah varians tiap butir 
$\sigma_{i}^{2}=$ Jumlah varians total

$\mathrm{N} \quad=$ Banyak peserta tes

$\mathrm{n} \quad=$ Banyak butir soal

Tingkat Kesukaran Soal : $P=\frac{B}{J S}$

Dengan ketentuan :

$\mathrm{P} \quad=$ Indeks kesukaran soal

$\mathrm{B}$ =Banyaknya siswa yang menjawab soal dengan benar

$\mathrm{JS}=$ Jumlah seluruh peserta tes

Daya Pembeda Soal : $D=\frac{B_{A}}{J_{A}}-\frac{B_{B}}{J_{B}}$

Dengan ketentuan:

$\mathrm{D}=$ Daya pembeda (Diskriminasi)

$\mathrm{B}_{\mathrm{A}}=$ Banyaknya peserta kelompok atas yang menjawab dengan benar

$\mathrm{B}_{\mathrm{B}}=$ Banyaknya peserta kelompok bawah yang menjawab dengan benar

$\mathrm{J}_{\mathrm{A}}=$ Banyaknya peserta kelompok atas

\section{Teknik Analisa Data}

\section{(a) Analisis kreativitas belajar biologi Siswa}

Adapun rumus yang digunakan untuk mengetahui tingkat kreativitas belajar siswa ( KBS) digunakan rumus :

\section{kreativitas belajar siswa \\ $=\frac{\text { jumlah skor siswa }}{\text { jumlah skor maksimal }} \times 100 \%$}

Daftar nilai angket digunakan untuk mengetahui kreativitas belajar siswa. Selanjutnya dari hasil data yang diperoleh pada setiap siklus kemudian dianalisis secara diskriptif kualitatif dengan menghitung persentase kreativitas belajarnya.

$$
P=\frac{\sum n_{1}}{\sum n} \times 100 \%
$$

Dimana:

$\mathrm{P} \quad=$ nilai ketuntasan belajar

$\sum n_{1}$, =jumlah siswa tuntas belajar individual (persentase $>65 \%$ )

$\sum n=$ jumlah total siswa

\section{(b) Analisa Data Aktivitas Siswa}

Persentase siswa $=$

$\frac{\text { Frekuensi Setiap Aspek Pengamatan }}{\text { Jumlah Frekuensi Semua Aspek Pengamatan }} \times 100 \%$

\section{HASIL DAN PEMBAHASAN}

Hasil penelitian diuraikan dalam tahapan yang berupa siklus. Siklus pembelajaran yang dilakukan dalam proses belajar mengajar di kelas XI-1 Madrasah Aliyah Nahdatul Ulama Batang Toru Tahun pelajaran 2016-2017. Pada siklus I mulai diperkenalkan pembelajaran dengan materi struktur dan fungsi jaringan tumbuhan melalui penerapan metode Quantum Teaching. Siklus I dilaksanakan dua kali pertemuan dimana pada pertemuan pertama dilaksanakan hari Rabu, 20 Juli 2016 dan pertemuan kedua dilaksanakan hari Rabu, 27 Juli 2016 dengan alokasi waktu $2 \times 45$ menit setiap pertemuan. Siklus I dihadiri oleh 26 orang siswa dan satu observer sebagai kolaborator. Hasil tes kreativitas belajar yang diperoleh siswa pada siklus I dapat dilihat pada gambar 1:

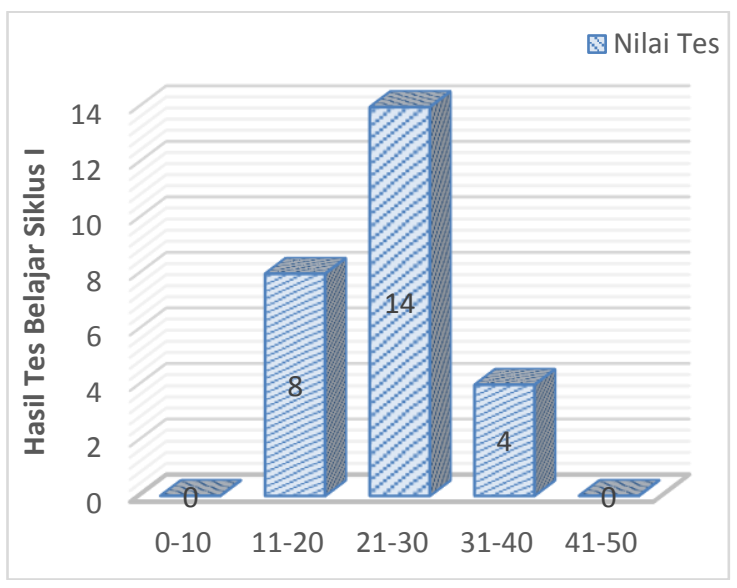

Gambar 1: Hasil tes kreativitas belajar Siswa Siklus I

Dari diagram batang di atas dilihat hasil tes kreativitas belajar dari siklus I bahwa frekuensi dari skor 11-20 sebanyak 8 siswa, 21-30 sebanyak 14 siswa, 31-40 sebanyak 4 siswa. Rendahnya nilai tes yang diperoleh siswa dikarenakan siswa masih 
Herdiani, dkk. Meningkatkan Kreativitas Belajar Biologi...

beradaptasi dengan model yang baru diterapkan.

Dari hasil observasi aktivitas siswa diproleh hasil bahwa pada indikator nomor 1 (Antusias siswa dalam mengikuti kegiatan pembelajaran) dengan rata-rata $61,53 \%$, pada indikator 2 (Intraksi siswa dengan guru) dengan rata-rata $65,38 \%$, pada indikator 3 (Intraksi siswa dengan siswa) dengan rata-rata $69,23 \%$, pada indicator 4 (Kerjasama kelompok) dengan rata-rata $65,38 \%$ dan pada Indikator 5 (Aktivitas belajar siswa dalam diskusi kelompok) dengan rata-rata 73,07\%. Hasil observasi tersebut menyatakan bahwa aktivitas belajar siswa pada siklus I masih kurang (Gambar 2.).

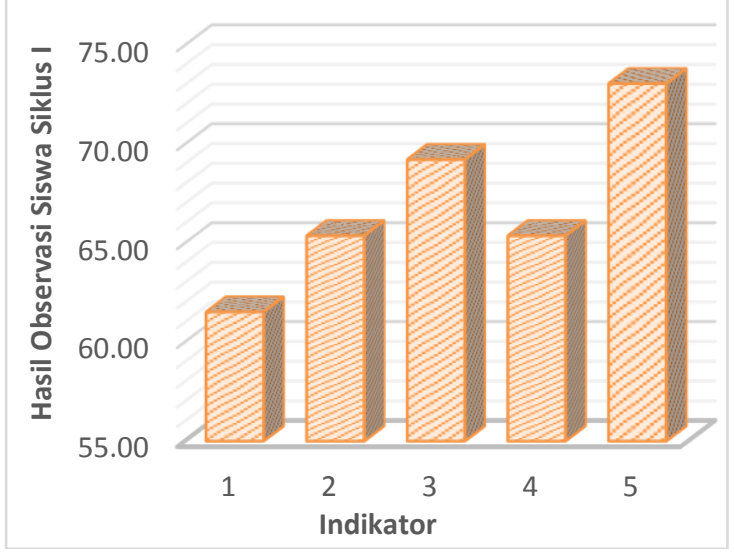

Gambar 2: Hasil observasi aktivitas siswa Siklus I

Berdasarkan lembar observasi kinerja guru pada siklus I tergolong kurang dengan total persentase yaitu $67,25 \%$, dan hasil observasi terhadap guru belum mencapai indikator keberhasilan yaitu $75 \%$. Peneliti memutuskan akan melanjutkan observasi kinerja guru ke siklus II sebab ingin melihat peningkatan kinerja yang lebih baik. Hal ini dapat dilihat pada gambar 3 .

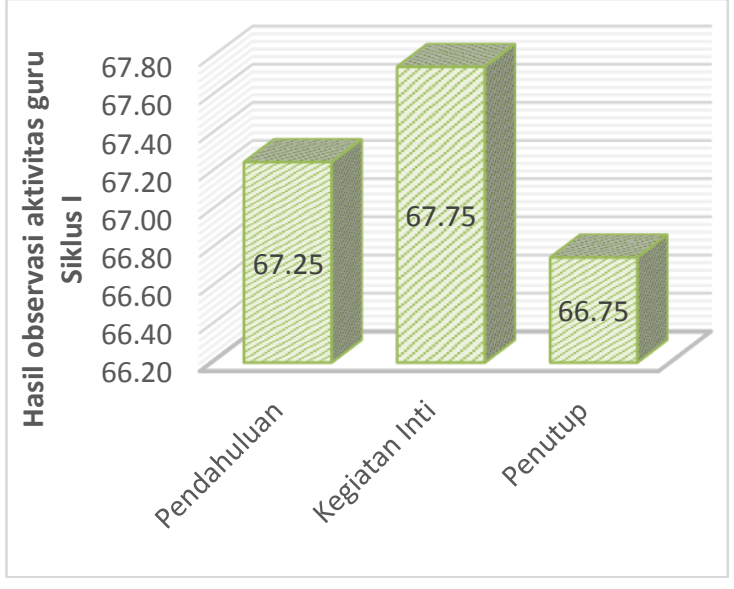

Gambar 3: Hasil observasi aktivitas guru Siklus I

Dari data yang diperoleh pada siklus I maka dapat disimpulkan bahwa siklus ini belum berhasil, hal ini dikarenakan beberapa factor seperti:

a. Guru belum mampu menyampaikan tujuan pembelajaran dengan baik, Tujuan pembelajaran merupakan bagian penting dalam proses pembelajaran sebab dengan mengetahui tujuan yang akan dicapai dapat membangkitkan dorongan dan semangat yang kuat pada siswa dalam pembelajaran sehingga siswa berupaya untuk dapat mencapai tujuan tersebut.

b. Pengelolaan kelas belum baik, sehingga banyak siswa yang ribut.

c. Aktivitas belajar pada diri siswa masih kurang diperoleh dari hasil observasi dengan persentase $69,92 \%$ hal ini disebabkan karena siswa belum terbiasa dengan metode Quantum Teaching

Melihat hasil refleksi di atas peneliti mengambil kesimpulan untuk melanjutkan penelitian pada siklus II, Untuk memperbaiki kekurangan dan mempertahankan keberhasilan yang telah dicapai pada siklus I, Maka pelaksanaan siklus II dapat dibuat perencanaan sebagai berikut:

a) Memberikan pengarahan untuk meningkatkan kreativitas siswa.

b) Mengontrol siswa dengan lebih baik dalam melakukan berbagai tahap pembelajaran. 
c) Memberikan penghargaan terhadap siswa yang prestasinya meningkat.

d) Menjelaskan kepada siswa bahwa metode Quantum Teaching merupakan salah satu model pembelajaran yang dapat meningkatkan kreativitas belajar biologi siswa.

Pelaksanaan tindakan pada siklus II ini bertujuan untuk melihat peningkatan pelaksanaan model pembelajaran seperti pada siklus pertama, siklus kedua ini terdiri dari perencanaan, pelaksanaan, observasi, dan refleksi. Siklus II dilaksanakan pada pertemuan ketiga hari Rabu, 10 Agustus 2016 dan pertemuan keempat dilaksanakan hari Rabu, 17 Agustus 2016 dengan alokasi waktu $2 \times 45$ menit setiap pertemuan. Siklus II ini dihadiri oleh 26 orang siswa dan satu observer sebagai kolaborator.

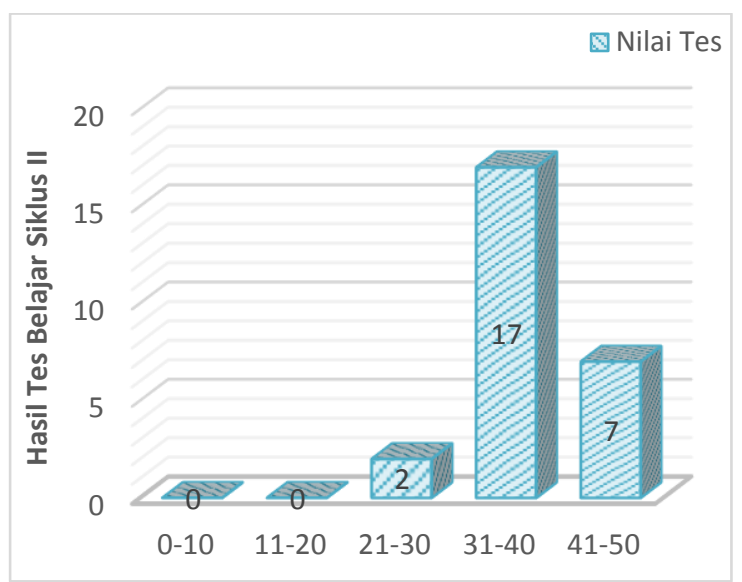

Gambar 4: Hasil tes kreativitas belajar Siswa Siklus II

Kreativitas belajar biologi siswa terhadap materi struktur dan fungsi jaringan tumbuhan tergolong sangat baik, dari 26 orang siswa yang mengikuti tes kreativitas, 7 orang siswa $(26,92 \%)$ yang tergolong sangat tinggi, 17 orang siswa $(65,38 \%)$ yang memperoleh kategori tinggi, yang memperoleh kategori cukup 2 orang siswa $(7,69 \%)$, Nilai rata-rata siswa diperoleh sebesar 38,03. dari hasil ini juga menunjukkan bahwa kreativitas siswa sudah mencapai nilai ketuntasan yang diharapkan yaitu $75 \%$ dari seluruh siswa. Hal ini menunjukkan bahwa kreativitas belajar biologi siswa telah mencapai indikator yang ditetapkan yaitu $<75 \%$ dari seluruh siswa yang mengikuti tes. Berdasarkan hasil tersebut maka penelitian dihentikan pada siklus ini karena sudah memenuhi indikator pencapaian penelitian yang ditetapkan (gambar 4).

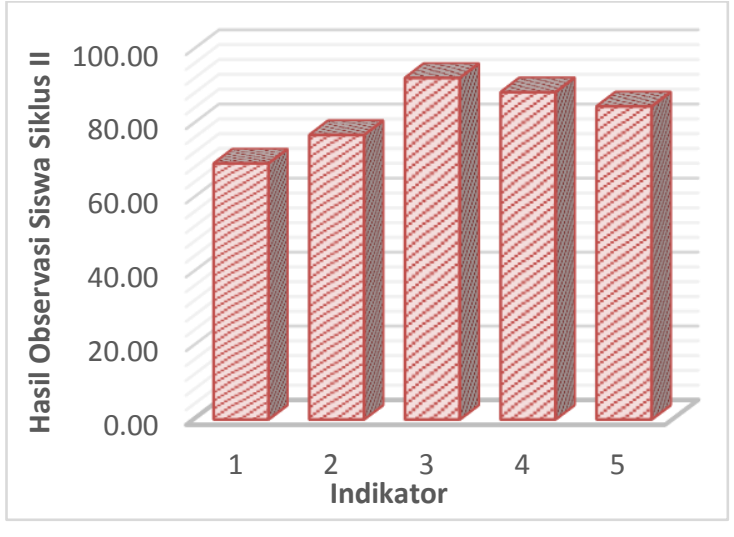

Gambar 5: Hasil observasi aktivitas siswa Siklus II

Observasi aktivitas siswa diperoleh hasil bahwa pada indikator nomor 1 (Antusias siswa dalam mengikuti kegiatan pembelajaran) dengan rata-rata $69,23 \%$, pada indikator 2 (Intraksi siswa dengan guru) dengan rata-rata $76,92 \%$, pada indikator 3 (Intraksi siswa dengan siswa) dengan rata-rata $92,3 \%$, pada indikator 4 (Kerjasama kelompok) dengan rata-rata $88,46 \%$ dan pada Indikator 5 (Aktivitas belajar siswa dalam diskusi kelompok) dengan rata-rata $84,61 \%$.

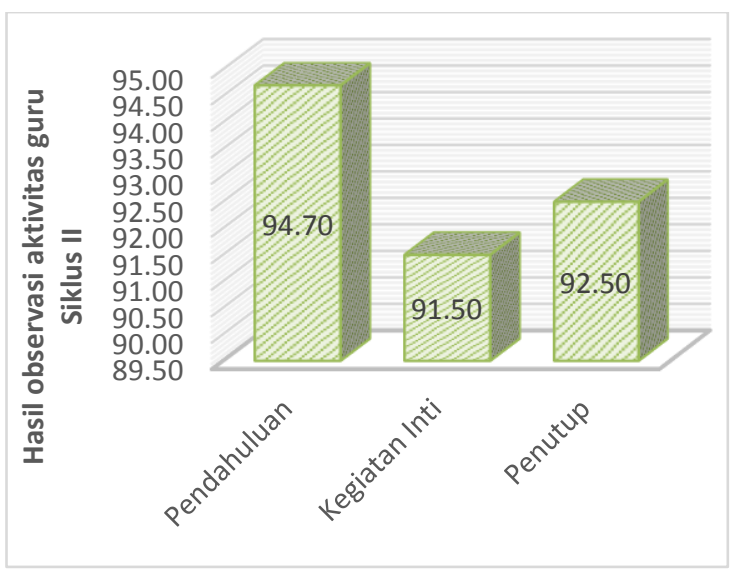

Gambar 6: Hasil observasi aktivitas guru Siklus II 
Herdiani, dkk. Meningkatkan Kreativitas Belajar Biologi...

Berdasarkan lembar observasi kinerja guru pada siklus II sudah tergolong amat baik yaitu dengan persentase $92,90 \%$ sudah memenuhi indikator keberhasilan $75 \%$. Hal ini membuktikan bahwa kinerja guru semakin meningkat.

Penelitian ini berakhir setelah selesai pelaksanaan siklus II, karena telah mencapai indikator keberhasilan yang telah ditetapkan. Pada siklus I, perolehan nilai siswa berdasarkan kreativitas belajar siswa 1872 dengan rata-rata 72 denganpersentase ketuntasan $(61,5 \%)$ yang memperoleh nilai $>75$ dan setelah dilaksanakan siklus II nilai kreativitas belajar siswa telah mencapai 2191 atau 84,27 dengan persentase ketuntasan $(84,62 \%)$. Hal ini sesuai dengan penelitian Sukuriyah dan Sujadi (2015) yang mengatakan bahwa dengan penerapan model pembelajaran Quantum Teaching dapat meingkatkan kreatifitas siswa.

Berdasarkan hasil observasi aktivitas belajar siswa dengan penerapan metode Quantum Teaching telah meningkat, dimana pada siklus I aktivitas siswa dalam pembelajaran cukup baik, tapi belum mencapai indikator yang telah ditetapkan, yaitu pada siklus I diproleh 66,97 pada kategori cukup, kemudian pada siklus II 82,30 berada pada kategori baik dan telah mencapai indikator keberhasilan yang ditetapkan. Menurut Amirotun $d k k$. (2013), penerapan model Quantum Teaching dapat meningkatkan keaktifan belajar siswa.

Berdasarkan hasil observasi kinerja guru dengan penerapan metode Quantum Teaching telah meningkat, dimana pada siklus I kinerja guru dalam pembelajaran cukup baik, tapi belum mencapai indikator yang telah ditetapkan, yaitu pada siklus I diproleh $67,25 \%$ pada kategori cukup, kemudian pada siklus II $92,7 \%$ berada pada kategori baik dan telah mencapai indikator keberhasilan yang ditetapkan. Amirotun dkk. (2013), menyatakan bahwa dengan penerapan model Quantum Teaching penguasaan guru terhadap kelas semakin baik, proses belajar siswa juga semakin baik sehingga hasil belajar siswa dapat meningkat.

Berdasarkan hasil diatas dapat disimpulkan bahwa guru telah mampu menerapkan metode Quantum Teaching pada materi struktur dan fungsi jaringan tumbuhan di kelas $\mathrm{XI}^{1}$ Madrasah Aliyah Nahdatul Ulama Batang Toru tahun pelajaran. 2016-2017 dengan baik sehingga dapat meningkatkan kreativitas belajar biologi siswa dan juga aktivitas siswa dalam belajar.

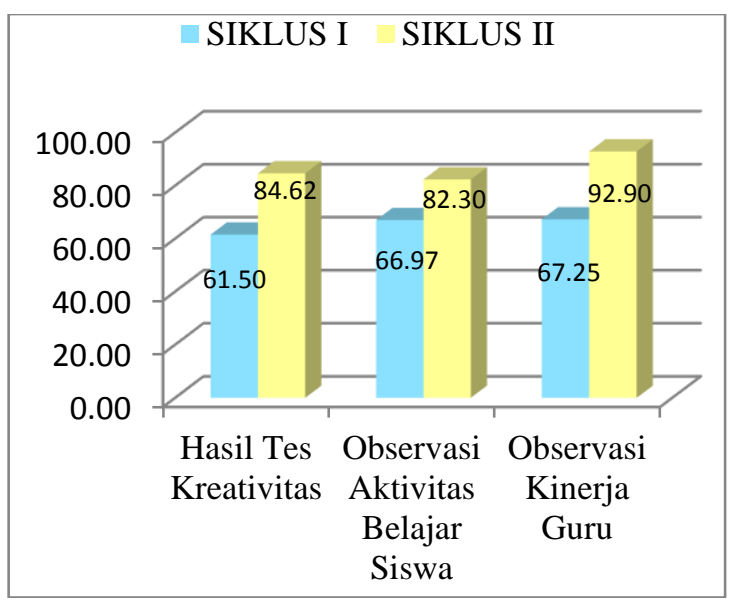

Gambar 7: Hasil Seluruh Penelitian Siklus I dan II

\section{KESIMPULAN}

Hasil penelitian menunjukkan bahwa Kreativitas belajar biologi siswa pada materi struktur dan fungsi jaringan tumbuhan di kelas XI meningkat, ditandai dari hasil tes kreativitas belajar biologi siswa, pada siklus I diperoleh 1872 dengan rata-rata 72 dengan persentase ketuntasan $(61,50 \%)$, sedangkan pada siklus II diperoleh 2191 dengan rata-rata 84,62 dengan persentase ketuntasan $(84,62 \%)$. Metode Quantum Teaching dapat meningkatkan kreativitas belajar biologi siswa. Hal ini dapat dilihat dari hasil observasi siswa, pada siklus I diperoleh persentase sebesar $66,92 \%$ dan siklus II diperoleh persentase $82,30 \%$. Penerapan metode Quantum Teaching dapat meningkatkan kinerja guru. Hal ini dapat dilihat dari hasil observasi kinerja guru, 
pada siklus I diperoleh persentase sebesar $67,25 \%$ dan siklus II diperoleh persentase $92,9 \%$.

\section{DAFTAR PUSTAKA}

Amirotun, S., Wahyudi dan Kartika Chrysti S. (2013). Penerapan Model Quantum Teaching dalam Peningkatan Pembelajaran IPS Siswa Kelas IV SD Negeri Sidomulyo. Kalam Cendikia. Vol.4, No.2.

De Porter, B, (2004). Quantum Teaching. Jakarta: Kaifa..

Dimyati, dan Mudjiono, (2006). Belajar dan Pembelajaran. Jakarta: Rineka Cipta.
Sukuriyah dan A. A. Sujadi, (2015). Penggunaan metode quantum teaching untuk Meningkatkan kreativitas dan prestasi Belajar matematika siswa kelas VIIA Smp taman dewasa ibu pawiyatan Yogyakarta tahun ajaran 2013/2014. UNION: Jurnal Pendidikan Matematika. Vol.3, No.1.

Suryosubroto, B, (2009). Prosedur Belajar Mengajar di Sekolah, Jakarta: Rineka Cipta. 